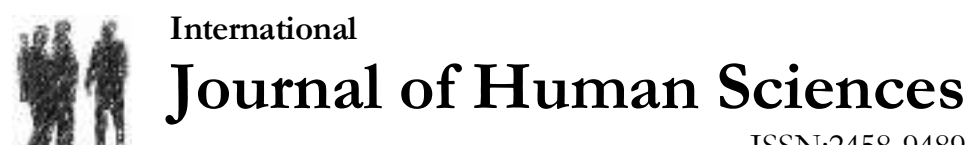 \\ ISSN:2458-9489
}

Volume 14 Issue 4 Year: 2017

\section{Quality of preservice teachers argumentation in socioscientific issues context ${ }^{1}$}

\author{
Dilek Karışan ${ }^{2}$ \\ Özgül Y1lmaz Tüzün ${ }^{3}$ \\ Dana Lewis Zeidler ${ }^{4}$
}

\begin{abstract}
This study aimed to explore preservice teachers' (PTs) argumentation quality during socioscientific issues (SSI) based classroom discussions. The participants of the study were 20 PTs from the Department of Elementary Education at a large, research oriented public university in Turkey. Qualitative case study method was used in this study. The study covered four socioscientific issues (food additives, alternative energy sources, climate change, and the industrial revolution). Each issue was discussed in the classroom and each discussion was video recorded. Video recordings were transcribed verbatim and used as data source. Classroom discussions verbatim transcribes were analyzed by using a modified version of Toulmin's argumentation pattern (TAP) model. The modified approach was found to be more conducive to informal argumentation patterns, in order to analyze preservice teachers' use of claims, grounds, warrants, backings, and rebuttals that support their debate positions, as well as their ability to use evidence-based reasoning, form coherent lines of reasoning, and use of correct (appropriate) evidence. Results of the study revealed that preservice teachers' use of evidence to support conflicting ideas tended to increase as their use of incorrect or insufficient use of evidence decreased through the present study.
\end{abstract}

Keywords: Argumentation; socioscientific issues; preservice teachers; critical thinking.

\section{Introduction}

Current science education reforms indicated that the goal of science education is not only to teach scientific concepts but also to help students understand societal problems (Erduran and Jimenez-Aleixandre, 2007). Socioscientific issues address these societal problems. Effective argumentation requires teaching higher order thinking skills and teaching content regarding socioscientific issues (Duschl, 2007). The characteristics of argumentation with its social, verbal, and intellectual features are helpful to engage students with ill-structured problems. Hence, argumentation frameworks are commonly used in science education literature for analyzing reasoning in the context of students engaging in socioscientific discourse.

\footnotetext{
1 This research was compiled from a part of a doctoral dissertation completed at Middle East Technical University Social Sciences Institute.

2 Assistant Professor, AdnanMenderes University, Faculty of Education, Department of Science and Mathematic Education, dilekkarisan@gmail.com

${ }^{3}$ Prof. Dr., Middle East Technical University, Faculty of Education, Department of Science and Mathematic Education, ozgul@metu.edu.tr

${ }^{4}$ Prof. Dr, University of South Florida, Faculty of Education, Department of Science Education, zeidler@usf.edu
} 
Karıșan, D., Yılmaz Tüzün, Ö., \& Zeidler, D. L. (2017). Quality of preservice teachers argumentation in socioscientific issues context. Journal of Human Sciences, 14(4), 3504-3520. doi:10.14687/jhs.v14i4.4949

Classroom argumentation discourse is a social process where students have a chance to engage in active discussion, challenge their peers, justify their claims with evidence, and persuade their opponents (Evagorou and Osborne, 2013). Classroom discussions or collaborative argumentation requires students to discuss the issue in multiple ways; students can learn other's positions during these discussion (Schwarz, 2009). Questions prompted by the teacher or asked by the student to challenge their peers or to understand the issue in detail is considered a thinking process skill related to critical thinking (Cuccio-Schirripa and Steiner, 2000), and central to argumentation (Evagorou and Osborne, 2013).

Classroom discussions are investigated by many researchers because of their significant contributions to learning. For example, Gage and Berliner (1998) asserted that the reflection in group contexts contributes to meaningful and effective social learning. Reflective group discussions contribute to students' learning from each other (Yacoubian and BouJaoude, 2010). Resnick (2010) suggested that when students explicitly challenge each other's ideas, their reasoning gains become higher. The fruitfulness of argumentation encourages researchers to focus on students' argumentation skills. Özdem, Ertepınar, Cakiroglu, \& Erduran (2013) highlights the importance of educating preservice science teachers (PSTs) in argumentation practices so that they can scaffold argumentation in their future science classrooms as well as support students' argumentation.

Sampson and Blanchard (2012) highlighted the contributions of argumentation on students' understanding of the concepts and process of science. They stressed that there is a limited number of study that engage students in classroom discussions. One of the reasons for the rare implementation of argumentation, the authors assert, is teachers' lack of pedagogical knowledge to design lessons that engage students in argumentation. Therefore, they aimed to understand teachers' argumentation strategies used to engage their students in argumentation activities. Teachers relied on their past experiences and their content knowledge to explain a phenomen on rather than actual scientific data. Few of the teachers used data and evidence to support their claims. The lack of teachers' use of evidence, and their reliance on personal knowledge rather than scientific data is related to teachers being inexperienced to conduct effective argumentation with their students. Sampson and Blanchard (2012) suggested that science education researchers should help in-service and pre-service teachers learn more about the scientific argumentation. OzdemYilmaz, Cakiroglu, Ertepinar \& Erduran (2017) also highlighted teachers' role in argumentation in science education, they worked with science teachers and graduate students who will be the future teacher educators to explore their instructional strategies used for and in argumentation. They conducted the study during a graduate course, which was aimed at developing science teachers' theory and pedagogy of argumentation. They presented a coding framework for the exploration of science teachers' instructional practices while they are implementing argumentation-based lessons.

For the least ten years, science education researchers have been investigating ill-structured problems such as sun rays, mobile phones, genetically modified foods, gene therapy, nuclear power plants, and so on. Significant amount of research have focused on SSI in science classroom practices (Kølsto, 2001; Liu, Lin, and Tsai, 2011; Topcu, Sadler, and Yllmaz-Tüzün, 2010; Zeidler, Sadler, Applebaum, and Callahan, 2009) to engage students in controversial real life issues. SSI were used as a tool to raise PTs' curiosity, active engagement, and personal involvement as the issues are directly related to real life. SSI generally requires the use of scientific topics that have moral or ethical implications and compels students to engage in protracted dialogues and discussions. SSI found to be consistent with progressive aims of science education (Zeidler, Applebaum, and Sadler, 2011). The place of controversial issues in science education emphasized as follows:

It is now a commonplace in science education that the study of socioscientific issues by students constitutes a prime avenue for fostering scientific literacy of a kind that will prompt young people to familiarize themselves with science in action, to develop their capacity for evaluating the information made available to them on a daily basis, to make 
Karıșan, D., Yılmaz Tüzün, Ö., \& Zeidler, D. L. (2017). Quality of preservice teachers argumentation in socioscientific issues context. Journal of Human Sciences, 14(4), 3504-3520. doi:10.14687/jhs.v14i4.4949

decisions concerning controversial sociotechnical issues, and to take part in debates and discussions on sociotechnical controversies of concern to them. (Pouliot, 2008, p. 545).

Using SSI as the context of instruction gives students an opportunity to understand how moral, ethical and personal values permeate scientific issues (Zeidler et al., 2009). It is clearly stated that, for socioscientific issues, there are no clear-cut solutions, and the alternative solutions cannot be fully determined by empirical or theoretical evidence (Sadler, 2011). Researchers have conducted a significant amount of research in order to explore the effectiveness of argumentation in SSI context (Berland \& Hammer, 2012; Berland \& Reiser, 2009; Callahan et al., 2009).

Khisfe (2013) aimed to explore the influence of explicit argumentation instruction in the context of a socioscientific issue. Seventh grade students were engaged with water usage and safety issues. Students' understanding of the topic and the quality of their argumentations were explored by multiple data sources (questionnaire, interviews). The researcher focused on absence/presence of students' justifications of claims and evaluated the validity of justifications. The results of the study showed that SSI treatment enhanced the quality of argumentation (students support their arguments with more than one justification). The importance of SSI context was highlighted as being an optimal condition for classroom argumentation. The researcher also suggested that SSI helped the learners in their application of scientific ideas and reasoning on the issue, as well as the integration of moral, ethical, and social concerns relevant to the problem. Bell and Lederman (2003) aimed to explore factors that affect adults' decision-making procedures. They conducted a study with 21 science education professors and used four different technology-embedded scenarios consisting of fetal tissue implementation, global warming, the relationship between diet and cancer, and the relationship between smoking and cancer. Surprisingly, results of the study indicated that participants did not substantially use scientific evidence to make decisions on these issues. Social/ political issues, ethical considerations and personal values were the most dominant factors related to their decision making. In Khisfe's study using socioscientific issues are welcomed to enhance argumentation qualities, present study (although the participants have different charactersics i.e. preservice teachers in present study) also used SSI to enhance preservice teachers argumentation quality.

Similar to Bell and Lederman, Jimenez-Aleixandre and Pereiro-Munoz (2002) also conducted a study on an environmental management issue in order to explore 11th grade students' decision making-procedures. The study was conducted in biology and geology courses. The aim of the study was twofold. First was to study the components of knowledge and skills needed to reach a decision in socio-scientific contexts. Second aim was to identify them in classroom discourse. Researchers used environmental conflicts for constructing the context of the study. Audio and video recordings of small group discussions were used as data sources. Researcher explored two dimensions of decision making: (1) students use relevant knowledge in order to understand and make decisions about the problem; (2) students aim at processing source of knowledge and critical evaluation of authority for evaluating possible solutions to the problem. Results of the study indicated that students' decisions were dependent on their conceptual understanding of the issues as well as value judgments. Students' ecological considerations dominated their economic considerations.

Current study also used controversial issues which are; food additives, climate change, alternative energy sources, and factors related to the industrial revolution to explore preservice teachers' argumentation quality. These issues were selected for two main reasons: 1) because of their ubiquity in modern society (particularly in Turkey); 2) their facilitation of classroom discourse and argumentation. 
Karıșan, D., Yılmaz Tüzün, Ö., \& Zeidler, D. L. (2017). Quality of preservice teachers argumentation in socioscientific issues context. Journal of Human Sciences, 14(4), 3504-3520. doi:10.14687/jhs.v14i4.4949

\section{Purpose}

Quality in education relates to the quality of the work undertaken by a teacher, which has significant effects upon students. Therefore, the initial step is having experienced teachers to educate students. If teachers have competence and experience about these issues then they can be able to discuss responsibly to global issues. Teachers, experienced in argumentation and knowledge construction process, enable their students be able to discuss the socioscientific issues tempered by their own values, let them to actively engage in knowledge construction during classroom discussions. These procedures may support PTs' active engagement in everyday life issues. Thus, the aim of the present study was to explore the quality of preservice teachers' argumentation skills revealed in SSI context. To reach this purpose, PTs were engaged in ill-structured problems, stated their personal choices about the ill-structured issues, used their scientific knowledge during the classroom discussions, engaged cost-benefit analysis about the issues and understood the incomplete nature of ill- structured problems.

The practical significance of this study is manifested through its participants (preservice teachers). Human beings play a central role in all environmental problems such as water pollution, air pollution due to the transportation issue, food shortages, and exaggerated energy consumption, etc. Therefore, we need first and foremost to educate people. There is a general acceptance of teachers' importance in the education process. Every single teacher, whatever their major area (science, math or arts) is, responsible for contributing to students' responsible citizenship. To achieve this aim students should be given the opportunity to explore a wide range decisions, and developing a caring attitude towards critical aspects of social and eco-justice (Zeidler, Berkowitz, and Bennett, 2014). School science can play an important role for raising students' environmental awareness and attitudes only if teachers see the exploration of these issues as a part of their central science teaching mission. Exploring how teachers come to know about socioscientific issues and how they construct their critical stances on these kinds of issue is worth analyzing since their personal experiences on these issues may directly transfer how they may approach such issues with their future students.

The theoretical significance of the study is its contribution of empirical evidence in science education research regarding SSI. Socioscientific issue based curriculum is highlighted in previous research (Callahan, Zeidler, Cone, and Burek, 2005; Zeidler et al., 2009) argumentation (Walker and Zeidler, 2007) and epistemological development (Zeidler et al., 2009). However, there are limited numbers of studies those aim to document semester-long effects of SSI treatments specifically in SSI context. The current study aims to engage preservice teachers in SSI regarding global environmental problems. A semester long application provides evidence regarding pre-service teachers' reasoning progress and argumentation skills. Following research question guided the study;

RQ: What are the argumentation quality of preservice teachers engaged in an SSI based course?

\section{Method and material}

Qualitative case study research was used in this study. Merriam (1998) asserts that case study supports researcher to make an in-depth study within the natural conditions. The United States General Accounting Office (USGAO, 1990) defines case studies as "A method for learning about a complex instance, based on a comprehensive understanding of that instance obtained by extensive description and analysis of that instance taken as a whole and in its context" (p. 14). The case study approach was thought the be appropriate for this study, because the study was looking for an indepth understanding in the real life conditions in order to reflect PTs' perspectives within defined boundaries. It is highlighted that the aim of case study research is to understand a case in-depth. 
Karıșan, D., Yılmaz Tüzün, Ö., \& Zeidler, D. L. (2017). Quality of preservice teachers argumentation in socioscientific issues context. Journal of Human Sciences, 14(4), 3504-3520. doi:10.14687/jhs.v14i4.4949

\subsection{Participants of the study}

The researchers used the convenient sampling method because this sampling strategy relies on available subjects who are easily accessible. Another issue in participant selection was PTs willingness to participate in the study. It was important to have volunteer participants since the course aims to engage PTs in intellectually demanding activities such as argumentation, and socioscientific issues. The course was an elective course therefore; all of the participants were interested with the socioscientific issues and selected the course on purpose. One of the participants was a sophomore student; although her undergraduate program (Elementary Science Education) suggests taking elective courses on third or fourth year she took the course in advance. One of them was a senior student and was planning to graduate at the end of the semester, remaining of the participants, that is eighteen PTs, were junior students.

At the beginning of the course, 20 out of 23 PTs showed willingness to participate in the study. Of the 20 PTs, 19 were female, and 1 was male with a mean age of 21 years (ranging from 18-25). The participants were enrolled either in Early Childhood Education (ECE) or Elementary Science Education (ESE) program, therefore, participants had differing academic background. Participants, as being teacher candidates, attended some career programs including seminars, presentations, and activities with primary and elementary school students in order to enhance their professional development. One of the PTs volunteered for disabled students, she organized audiobook database at the assistive technology lab for students with visual impairments. Seven of PTs (ECE) taught elementary school children from low-income districts music and art, one of them worked as a babysitter (ECE students). One of them was working at toy library, an association in Ankara, as toy librarian. Three of the PTs (ESE) taught physics, chemistry, biology and math to children from low-income districts. There were two PTs, who were volunteers to work in a special education community to help disabled elementary students. The participants were aware of the importance of practicing these activities before graduation for their professional development. Out of 20,15 PTs reported that they attended at least one of above activities.

\subsection{Research Procedure}

Groups of four students, which were formed at the beginning of the semester, prepared power point presentations for one of the four issues, and were responsible for their presentation to the class. Students typically met and devoted time outside of class (e.g., weekends evenings) for presentation preparations to search library and internet databases for relevant information related to that issue, compile and analyze and synthesize information, and send their summary to course mentors. The course instructors were responsible for fact checking and providing feedback to the groups. Presentations include the controversial video presentations, striking magazines headlines, debatable articles and photographs. Course instructors encouraged the presenters to challenge core beliefs of their classmates during the presentations by providing leading questions to engage the class in discussion, reinforce key ideas, address multiple perspectives about the issue, construct moral positions and arguments, and deepen increase content familiarity. Classroom discussions were their chance to participate in an argumentation discourse.

\subsection{Data collection tools}

The argumentation patterns of PTs, developed in group discussions on each controversial issue, were used as data source. All discussions were video recorded and were transcribed in verbatim. These video transcriptions were used during analysis procedure. The aim of this analysis was to explore; how do PTs elaborate arguments while confronted to SSI in classroom discussions.

\subsection{Data analysis}

Classroom discussions were analysed by using a modified version of Toulmin's argumentation pattern (TAP) model drawing on the work of Walker and Zeidler (2007). The 
Karıșan, D., Yılmaz Tüzün, Ö., \& Zeidler, D. L. (2017). Quality of preservice teachers argumentation in socioscientific issues context. Journal of Human Sciences, 14(4), 3504-3520. doi:10.14687/jhs.v14i4.4949

modified approach was found to be more conducive to informal argumentation patterns, in order to analyze preservice teachers use of claims, grounds, warrants, backings, and rebuttals that support their debate positions, as well as their ability to use evidence-based reasoning, form coherent lines of reasoning, and use of correct (appropriate) evidence. This form of analysis allowed for the consideration of claims at multiple levels, as an interconnected set of related ideas, rather than restricting the focus to isolated frames of conversation. More specifically, present study did not focus on the identification of arguments in terms of an interconnected set of claims, data, warrants, backings etc. in the context of whole-class conversations rather did focus on holistic analysis by exploring the students' conceptual understanding of science content knowledge and the structure of their argument. The evaluation rubric included four levels (zero to three) that are used to rate the rounds of each student's conversational turns from the transcriptions of the classroom discussions. The coding scheme was as follows: Level 0 - no evidence or claims provided in justification; Level 1 - incorrect consideration of evidence, claims, warrants backings or rebuttals for opposing ideas related to subject matter knowledge); Level 2 - consideration of non-specific evidence, etc.; Level 3 - Correct consideration of specific evidence, etc. (Any off-topic discussions or directives were classified as "not rated"). Also, analyst triangulation (Patton, 2002) was conducted. Specifically, fifteen transcripts were randomly selected, blinded and independently scored by the first author and three doctoral student researchers who were well acquainted with the scoring rubric. Discussions were then held where raters had the opportunity to provide rationales for their assessments of the classroom discourse and form consensus on point of departure. Inter-rater agreement was over 90\%; however, after raters had the opportunity to "calibrate" their coding scheme with one another, consensus was established virtually assuring nearly full agreement. At that point, the first author scored the remaining transcripts individually. Table 1 provides an overview of exemplars used for the coding of argumentation patterns.

Table 1. Exemplars of Argumentation Level, Description and excerpts

\begin{tabular}{|c|c|c|}
\hline Level & Description & Sample Excerpts \\
\hline 0 & $\begin{array}{l}\text { No evidence claims or Subject Matter } \\
\text { Knowledge (SMK) are considered }\end{array}$ & $\begin{array}{l}\text { "People have no right to change the } \\
\text { nature of anything, even foods" }\end{array}$ \\
\hline 1 & $\begin{array}{l}\text { Incorrect consideration of } \\
\text { evidence claims or SMK }\end{array}$ & $\begin{array}{l}\text { [Processed food] lose their nutritional } \\
\text { value. For example, experts warn people } \\
\text { 'don't use a knife for your vegetables } \\
\text { use your hands to make them small.' } \\
\text { This explains everything, even a knife } \\
\text { reduces the nutritional value; additives } \\
\text { do much more }\end{array}$ \\
\hline 2 & $\begin{array}{l}\text { Consideration of non-specific } \\
\text { evidence claims or SMK }\end{array}$ & $\begin{array}{l}\text { [Additives] put too many chemicals } \\
\text { into your body that should not be there }\end{array}$ \\
\hline 3 & $\begin{array}{l}\text { Correct consideration of specific } \\
\text { evidence claims or SMK }\end{array}$ & $\begin{array}{l}\text {.. if the amount of additives are } \\
\text { regulated, they provide enhanced } \\
\text { vitamins and minerals (enhanced dairy } \\
\text { products)... improves taste and } \\
\text { appearance of the foods (colorful and } \\
\text { attractive pastries)... prevents bacteria } \\
\text { growth (longer shelf life)... provides } \\
\text { flavor enhancement (fructose corn } \\
\text { syrup). My only concern is the excess } \\
\text { amount of additives }\end{array}$ \\
\hline
\end{tabular}


Karıșan, D., Yılmaz Tüzün, Ö., \& Zeidler, D. L. (2017). Quality of preservice teachers argumentation in socioscientific issues context. Journal of Human Sciences, 14(4), 3504-3520. doi:10.14687/jhs.v14i4.4949

\subsection{The generalizability of the study}

Although the generalizability is not the issue for qualitative research we attempted to enhance trustworthiness of the study and increase external validity issues. External validity can be defined as transferring a study results into another study (Merriam, 1998). Lincoln and Guba (1985) explained external validity by the term applicability which refers to transferability. The question of external validity for this study is tried to be solved by thick descriptions of participants, data collection procedure, data collection tools and finally data analysis procedure (see section 3.6).

Lincoln and Guba (1985) presented a framework to enhance the trustworthiness of the qualitative studies. Trustworthiness of the current study was established based on the framework presented by Lincoln and Guba (1985). Three techniques was used in order to have valid and reliable findings which are triangulation, member checking, and providing thick description.

To enhance the reliability of the data, we used researcher triangulation to establish interrater reliability of the data analysis. Different researchers scored each paper line-by-line, and graded papers by using the related rubric (Argumentation). Two of the researchers reviewed the papers and assessed them independently. First and second author's scores compared to calculate the initial inter-rater reliability. There were some cases that the inter-rater reliability was below $90 \%$ we came together and discussed the scoring. The secondary inter-rater reliability was greater than $90 \%$, which was determined to be an acceptable level. Triangulation improved the quality of data analysis and the accuracy of the findings.

\subsection{Research ethics}

Researchers took permission from the Ethical Committee of the University where the research was conducted, and asked all preservice teachers to sign the consent form. On registration week, 23 PTs registered for the course. First week, researcher talked to every single PT, who registered the course, about course content. Participants were informed about the data collection procedure, video-recordings weekly interviews, and such. All of them were informed that there would be no harm or deception. Preservice teachers were explicitly informed about the course which was a doctoral dissertation implementation. The course was elective course so that PTs had a chance to drop the course in add-drop weeks. Some of the participants ( 3 of the 23 participants) who feel uncomfortable to participate in video-recording dropped the course on add-drop week and remaining twenty PTs willingly participated in this study. Researcher ensured that the confidentiality of data -video recordings, voice recordings would be protected, participants names would not be revealed anywhere. Randomly assigned numbers were used instead of real names.

As a requirement of the course, preservice teachers were asked to make presentations (once every two weeks), to address the issue from multiple perspectives in classroom discussions. All the participants were informed about the ill-structured problems. It is explained that there were no clear cut solutions for these problems and no true answer for an issue. Preservice teachers were aware of that there were no right answers to the problems. The researchers tried to encourage them share their ideas freely by clearly indicating that the aim was not to assess their answers as true or false response, but we aimed to evaluate their way of knowledge justification. Although the researcher aimed to reduce ethical issues in the current study, there is still a potential risk named as reactivity (Lincon and Guba, 1985) in qualitative research. The presence of the camera during the discussions of social ethical and environmental issues might change the students' interaction. Our interpretations based on preservice teachers' interactions while being recorded. The researcher tried to persuade the participants that the videos would be used only for research purpose in order to overcome this threat. She also spent time in the classroom to make the PTs got used to presence of camera. 
Karıșan, D., Yılmaz Tüzün, Ö., \& Zeidler, D. L. (2017). Quality of preservice teachers argumentation in socioscientific issues context. Journal of Human Sciences, 14(4), 3504-3520. doi:10.14687/jhs.v14i4.4949

\section{Results}

In order to assess the quality of preservice teachers' argumentation skills in the classroom discussion, Toulmin's (1958) model of argument was used. Each preservice teacher's turn (i.e., a single PT's contribution to the dialogue) was analyzed for his or her use of claims, grounds, warrants, backings, and rebuttals to support his or her claims. The researchers were interested in exploring what domains of knowledge the PTs would utilize to justify and debate their position in SSI context. The grounds of the PTs for making their claims were rated for their use of evidence. The discussions lasted four hours. Sample excerpts were presented for each level (Level 0 to Level 3 ) in Table 2, 3, 4, and 5 for food additives, alternative energy issues, climate change and industrial revolution issues respectively.

Food additives week, the history, types (i.e., food colorings, emulsifiers, sweeteners, flavorings, gelling agent, preservatives, anti-caking, antioxidants, and acidulants) advantages and disadvantages of food additives were discussed. Most of the PTs could construct a reason for their claims, but few PTs provided supporting evidence to back up their claims about food additives. The classroom discussions revealed that PTs have diverse opinions about using food additives. In total, there were 290 conversational turns in food additive debates. All participants attended the food additive discussion. Researchers rated each student's contribution to the discussion. PTs food additive discussions were transcribed in verbatim. Bearing it in mind, 290 lines of dialogue were analyzed for this issue. Table 2 examples of PTs' reasoning on food additives issue. The researcher aimed to give examples of Level-0, Level-1, Level-2 and Level-3 argumentations for food additives issue. Direct quotations from PTs' explanations, their argumentation categories and researchers rationale for rating those PTs as Level-0 or Level-3 was explained in the table. The frequency of each level, out of 290 turn, was also given.

Table 2. Examples of Rubric-rated Conversational Turns: Food Additives.

\begin{tabular}{|c|c|c|c|}
\hline Level & Excerpts & Argument Category & Freq. \\
\hline 0 & $\begin{array}{l}\text { People no right to change the nature of } \\
\text { anything, even foods. }\end{array}$ & Personal opinion. & 15 \\
\hline 1 & $\begin{array}{l}\text { They [processed food] lost their } \\
\text { nutritional value. For example, experts } \\
\text { warn people `don't use a knife for your } \\
\text { vegetables use your hands to make them } \\
\text { small. This explains everything, even } \\
\text { knife reduces the nutritional value; } \\
\text { additives do much more. }\end{array}$ & $\begin{array}{l}\text { Claim (foods lost nutritional } \\
\text { value) Ground (knife reduces the } \\
\text { nutritional value, then food } \\
\text { additives must reduce) }\end{array}$ & 23 \\
\hline 2 & $\begin{array}{l}\text { They [additives] put too many chemicals } \\
\text { into your body which should not be there. }\end{array}$ & $\begin{array}{l}\text { Claim (additives includes } \\
\text { chemicals) } \\
\text { Ground (chemicals should not } \\
\text { be taken into body) }\end{array}$ & 38 \\
\hline 3 & $\begin{array}{l}. . \text { if the amount of additives are regulated, } \\
\text { they provide enhanced vitamin's and } \\
\text { minerals (enhanced dairy products); } \\
\text { improves taste and appearance of the } \\
\text { foods (colorful and attractive pastries). } \\
\text { prevents bacteria growth (longer shelf } \\
\text { life); provides flavor enhancement } \\
\text { (fructose corn syrup). My only concern is } \\
\text { the excess amount of additives }\end{array}$ & $\begin{array}{l}\text { Claim (enhance flavor, improve } \\
\text { taste and appearance, prevents } \\
\text { bacteria growth). Ground (dairy } \\
\text { products), warrant (longer shelf } \\
\text { life). Backing (concern for the } \\
\text { excess amount). }\end{array}$ & 99 \\
\hline
\end{tabular}


Karışan, D., Yılmaz Tüzün, Ö., \& Zeidler, D. L. (2017). Quality of preservice teachers argumentation in socioscientific issues context. Journal of Human Sciences, 14(4), 3504-3520. doi:10.14687/jhs.v14i4.4949

Alternative Energy sources week PTs compared the sources whether they are renewable or not, what is their set up and ongoing operation costs, what size of energy storage is needed, and what impact will they have on the environment. They discussed the limited amounts of fossil fuels, increase in the amount of greenhouse gases because of burning of fossil fuels, and rapid change in climate. In total, there were 380 conversational turns in energy week. Numbers of conversational turns for energy issue were higher than the previous issue (food additives, 290 turns). PTs were familiar with energy issue since the issue is hot debated in Turkey, PTs were sensitive to this issue due to governments energy politics, the effects of Hydroelectric power plants' on cities, PTs personal experiences (people died from cancer due to Chernobyl) on the effects of nuclear power plants and etc. The increase in subject matter knowledge and the increase in personal experiences of the issue may cause the increase of PTs participation to the discussions. All participants attended the discussion hours. As previously indicated, classroom discussions does not always include a formal line of argument, sometimes informal conversations may happen. The researcher did not rate these informal conversations and reported the amount of those "not rated" turns in previous table. Table 3 presents some examples of the PTs' reasoning on alternative energy issue. The frequencies of each level (out of 380 turns) and direct quotations from PTs conversational turns were reported in the table.

Table 3. Examples of Rubric-rated Conversational Turns: Alternative Energy

\begin{tabular}{|c|c|c|c|}
\hline Level & Excerpts & Argument Category & Freq. \\
\hline 0 & $\begin{array}{l}\text { Other countries use nuclear energy so we } \\
\text { can use also. }\end{array}$ & Personal opinion. & 56 \\
\hline 1 & $\begin{array}{l}\text { I experienced Chernobyl disaster; my family } \\
\text { members suffered from cancer my uncle } \\
\text { died because of it. I against the use of } \\
\text { nuclear power plant. It makes people die. }\end{array}$ & $\begin{array}{l}\text { Claim (nuclear plants kill } \\
\text { people) evidence (her } \\
\text { uncles death) }\end{array}$ & 38 \\
\hline 2 & $\begin{array}{l}\text { In general, developing countries are } \\
\text { dependent to developed countries for } \\
\text { energy. We live in a global world so we can } \\
\text { not be totally independent. }\end{array}$ & $\begin{array}{l}\text { Claim (totally } \\
\text { independence is not } \\
\text { possible) } \\
\text { Ground (developing } \\
\text { countries are dependent } \\
\text { to developed countries, } \\
\text { globalization is the } \\
\text { reason) }\end{array}$ & 74 \\
\hline 3 & $\begin{array}{l}\text { Nuclear plants emit fewer greenhouse gases } \\
\text { during electricity generation than coal or } \\
\text { other traditional power plants. (no sulfur, } \\
\text { no carbon dioxide). We need predictable } \\
\text { energy sources. Wind or solar energy are } \\
\text { not stable; geothermal are location specific } \\
\text { so the most efficient [energy source] is } \\
\text { nuclear energy. }\end{array}$ & $\begin{array}{l}\text { Claim (most efficient } \\
\text { source is nuclear) } \\
\text { backing (limitations of } \\
\text { other energy sources) } \\
\text { Claim ( fewer } \\
\text { greenhouse gas) } \\
\text { Evidence (no sulfur, no } \\
\text { carbon dioxide) }\end{array}$ & 97 \\
\hline
\end{tabular}

The Climate change issue The PTs discussed the climate change issue. The aim of the discussion was to deepen PTs' understanding of disputes over climate change and the human contribution to it. The question was: Is climate change man-made? The both side of the issue has been discussed and they had diverse views about the issue. In total, there were 197 conversational 
Karıșan, D., Yılmaz Tüzün, Ö., \& Zeidler, D. L. (2017). Quality of preservice teachers argumentation in socioscientific issues context. Journal of Human Sciences, 14(4), 3504-3520. doi:10.14687/jhs.v14i4.4949

turns in climate change week. The whole participants attended class hours, and all of them contributed to the discussion. There were three PTs $(3,12,18)$ that accounted for the majority of the student dialogue. These PTs took different positions relative to the climate change issue from time to time during the discussion. They challenged their peers' view. Although the opponents were outnumbered, they presented level-3 argumentation. They had adequate subject matter knowledge and grounded their positions using accurate evidence. There were some informal conversations (41 out of 197 conversation turns) during the discussion which were not rated by the researcher. Examples of each level, from zero to three, argumentation for climate change issue was presented in Table 4.

Table 4. Examples of Rubric-rated Conversational Turns: The Climate Change.

\begin{tabular}{|c|c|c|c|}
\hline Level & Transcript dialogue & $\begin{array}{l}\text { Argument } \\
\text { Category }\end{array}$ & Freq. \\
\hline 0 & $\begin{array}{l}\text { How can deodorant affect the climate? I do not } \\
\text { believe that there is a relationship. }\end{array}$ & $\begin{array}{l}\text { No evidence and } \\
\text { SMK }\end{array}$ & 14 \\
\hline 1 & $\begin{array}{l}\text { If the ozone hole is maximum in polar region, } \\
\text { maximum CC must occur in that region, but we } \\
\text { know, people live in Equator region much more } \\
\text { suffer from it [Climate Change]. Isn`t it a } \\
\text { contradiction? }\end{array}$ & $\begin{array}{l}\text { Claim (CC must } \\
\text { occur in the polar } \\
\text { region). } \\
\text { Evidence (ozone } \\
\text { hole is maximum in } \\
\text { polar region) }\end{array}$ & 22 \\
\hline 2 & $\begin{array}{l}\text { These are expected scenarios (computer } \\
\text { prediction for } \mathrm{CO}_{2} \text { level) we can block rapid } \\
\text { increase, as a result, it is up to you to ignore it } \\
{[\mathrm{CC}] \text { or regulate. }}\end{array}$ & $\begin{array}{l}\text { Claim (we can block } \\
\text { rapid increase) }\end{array}$ & 59 \\
\hline 3 & $\begin{array}{l}\text { We can see the CC on NASA photographs, } \\
\text { surface area of Arctic sea ice has declined rapidly } \\
\text { over the last several decades. Where does ice } \\
\text { goes? Melting! Unsurprisingly, sea level rise. }\end{array}$ & $\begin{array}{l}\text { Claim (arctic ice } \\
\text { melting) } \\
\text { Evidence (decline in } \\
\text { arctic sea ice) } \\
\text { Warrant (sea level } \\
\text { rise) }\end{array}$ & 61 \\
\hline
\end{tabular}

The Industrial revolution was the last but not the least issue. PTs became familiar with the developments in the food sector, the alternative energy sources, and the climate change issue in previous weeks. Discussing the effects of the revolution on society gave a broader perspective to PTs about these issues due to the direct relationship between the Industrial Revolution and current socio-scientific issues (mobile phones, air pollution due to transportation, burning fossil fuels, releasing greenhouse gases, genetically modified foods). Undoubtedly, the revolution was major turning point in history; almost every aspect of daily life was influenced. In total, there were 183 conversational turns for the Industrial Revolution issue. Twenty-one conversational turns were labeled out of content so they were "not rated" 5 turns of the opponents and 8 turns of the proponents did not include any reference to the information (rating=0), 14 turns of the proponents and 23 turns of the opponents used incorrect consideration of the evidence or subject matter knowledge (rating=1). The level 2 (41 turns) and level 3 (71turns) PTs have adequate subject matter knowledge and grounded their positions using accurate evidence. Examples of each level, from zero to three, argumentation for industrial revolution issue was presented in Table 5. 
Karışan, D., Yılmaz Tüzün, Ö., \& Zeidler, D. L. (2017). Quality of preservice teachers argumentation in socioscientific issues context. Journal of Human Sciences, 14(4), 3504-3520. doi:10.14687/jhs.v14i4.4949

The frequencies of each level were also presented. PTs ways of reasoning on the Industrial Revolution issue can be seen from direct quotations in table.

Table 5.1 Examples of Rubric-rated Conversational Turns: Industrial Revolution.

\begin{tabular}{|c|c|c|c|}
\hline Level & Transcript dialogue & Argument Category & Freq. \\
\hline 0 & $\begin{array}{l}\text { Human being made the revolution, so human being can } \\
\text { stop it. There is no need to concern about it. }\end{array}$ & $\begin{array}{l}\text { Claim (the effects of } \\
\text { revolution can be } \\
\text { stopped) }\end{array}$ & 13 \\
\hline 1 & $\begin{array}{l}\text { The numbers of factories increased by the industrial } \\
\text { revolution this increased employment opportunity and } \\
\text { wealth of the society; people can be able to find a job } \\
\text { easily. }\end{array}$ & $\begin{array}{l}\text { Claim (new job } \\
\text { opportunity, wealth) } \\
\text { Ground (increase in } \\
\text { the number of } \\
\text { factories) }\end{array}$ & 37 \\
\hline 2 & The IR changed human life drastically. & $\begin{array}{l}\text { Claim (drastically } \\
\text { change) }\end{array}$ & 41 \\
\hline 3 & $\begin{array}{l}\text { Well, the other side of the coin shows us the revolution } \\
\text { polluted the air. I mean.. Factories use excess of coal } \\
\text { and fuel. This is what we suffer from in today's world. } \\
\text { Wars because of fuel, pollution, health problems... }\end{array}$ & $\begin{array}{l}\text { Claim (revolution } \\
\text { polluted the air) } \\
\text { Ground (factories use } \\
\text { excess of coal and } \\
\text { fuel } \\
\text { Backing (we suffer } \\
\text { from pollution, health } \\
\text { problems) }\end{array}$ & 71 \\
\hline
\end{tabular}

Figure 1 shows the percentage of each argumentation patterns across four socioscientific issues.

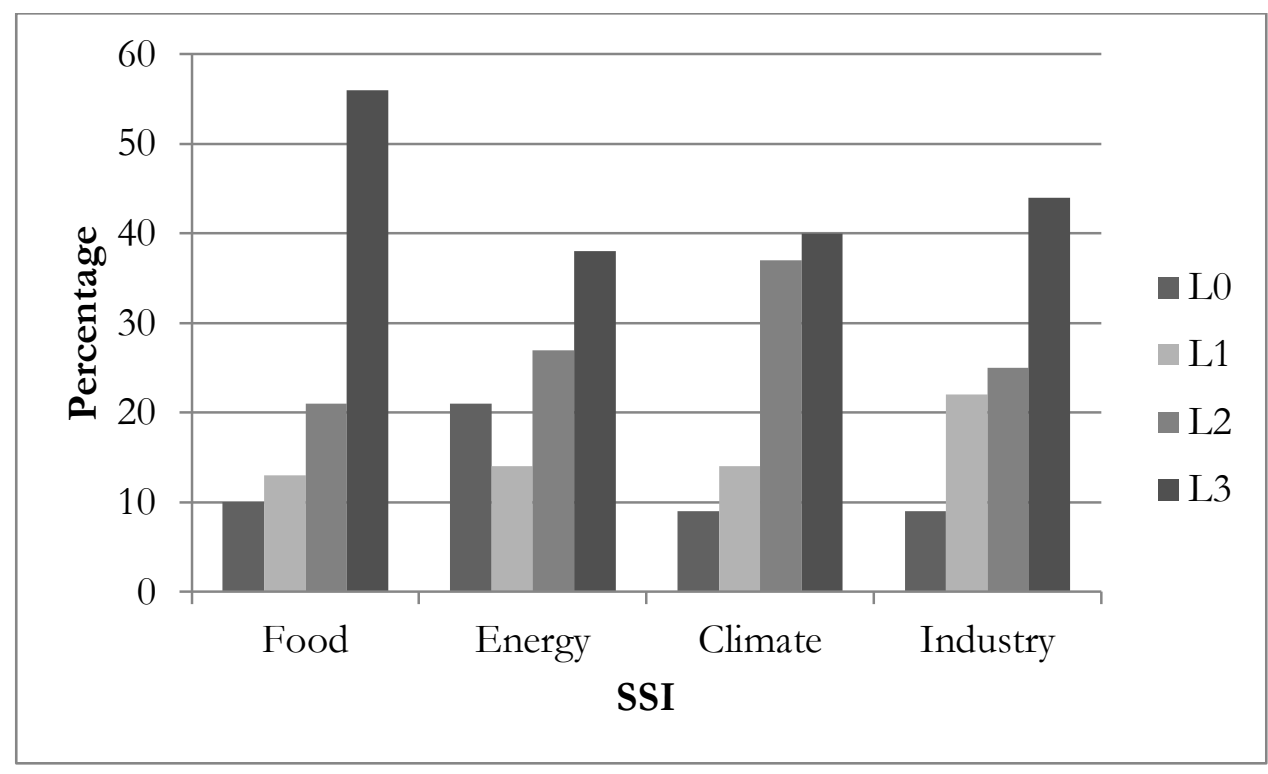

Figure 1 Percentage of argumentation levels across different SSI 
Karıșan, D., Yılmaz Tüzün, Ö., \& Zeidler, D. L. (2017). Quality of preservice teachers argumentation in socioscientific issues context. Journal of Human Sciences, 14(4), 3504-3520. doi:10.14687/jhs.v14i4.4949

Based on the results shown in Figure 1, it was observed that varying levels of argumentation patterns were obtained across SSI contexts. As it was presented in the methods section, preservice teachers' responses were coded as Level 0 if they did not provide claims or evidences in their responses. Relying on personal experiences that were meaningful to that person rather than focusing on scientific data was common across Level 1 PTs. For example, Preservice Teacher (PT)3 supported using sweeteners because her grandmother was diabetic and the doctor treating her banned sugar and suggested using sweeteners. PT-15 rejected the use of food additives because of religious reasons. She asserted that people does not have right to interfere with the nature order of anything; she is against food additives, human cloning, gene therapy etc., believing that it is God's decision and people have no right to interfere with it. The percentages of Level 0 arguments were same for food additives, climate change and the industrial revolution (9\%). However, for alternative energy, this percentage was two times higher than other issues $(21 \%)$. This result indicates that for the alternative energy issue, the students have a higher tendency to rely on their personal thoughts with or without considering scientific evidence.

Preservice teachers' incorrect considerations of evidence, claims, warrants, backings or rebuttals for opposing ideas was coded as Level 1 . Observed percentages for Level 1 were close to each other for food additives, alternative energy and climate change (range 13-14\%) but it was almost doubled for the industrial revolution issue (22\%). We believe that because of the complex nature of socioscientific issues, these preservice teachers were uncertain and inexperienced about entertaining potential opposing ideas and evidence. This situation was consistently observed throughout the course. The preservice teachers' incorrect consideration of evidence or claims for opposing ideas was frequently observed in the industrial revolution context. Few preservice teachers were able to provide a rebuttal without simply restating their own position and few preservice teachers used science subject matter in their answers. It was also found that preservice teachers did not understand or recognize valid sources of evidence during decision-making for this issue. Level 1 preservice teachers attempted to evaluate risks and benefits for the industrial revolution issue. However, the robustness of their explanations fell short in that they were either unable to have a critical eye or possessed inadequate subject matter knowledge about the issue. For example, one student claimed that the increased in number of factories during the industrial revolution also increased the employment opportunities and wealth of the society. That student's explanation was inadequate since the machines invented replaced human labor causing many to lose the ability to sustain incomes for their families. As a whole, classroom conversations revealed that although the preservice teachers were familiar with the industrial revolution issue, they were still unable to coordinate evidence to support their ideas.

Preservice teachers' consideration of non-specific evidence, claims or subject matter knowledge was coded as Level 2. As Figure 1 indicates, preservice teachers' displayed higher levels of argumentation (Level 2 and Level 3) with greater frequency than Level 0 and Level 1 throughout the investigation. This is encouraging, as we would hope that preservice science teachers could select correct evidence and valid claims to support their positions. The highest frequency for Level 2 was observed for the issue of climate change. Thus, preservice teachers mostly used non-specific evidence for their claims in this issue. This might reasonably be expected because of the complex nature of climate change issues.

Finally, we examined argumentation frequencies for preservice teachers' ability to utilize correct evidence or appropriate subject matter knowledge (coded as Level 3). We found that preservice teachers applied the correct use of evidence or subject matter knowledge in the following manner: food additives (57\%), $38 \%$ for alternative energy, $40 \%$ for climate change, and $44 \%$ for industrial revolution. If one assumed that preservice teachers would simply perform better with practice, we would expect to see a steady rise in the level of argumentation sophistication over time. Since we have presented the SSI in Figure 1 in the order in which they were investigated over the semester, clearly performance is not simply the result of familiarity with the SSI tasks over time (in one semester). If that were the case, one would expect performance to consistency improve 
Karıșan, D., Yılmaz Tüzün, Ö., \& Zeidler, D. L. (2017). Quality of preservice teachers argumentation in socioscientific issues context. Journal of Human Sciences, 14(4), 3504-3520. doi:10.14687/jhs.v14i4.4949

over time. This suggests that there are more contextual factors in play, whereby student are better able to identify with or be more willing to invest themselves in a given issues because of their personal cognitive or affective preferences.

\section{Discussion}

Analysis of preservice teachers' argumentation also revealed a range of quality across SSI. Level zero argumentation quality was observed as the lowest frequency across each SSI. The analysis of responses level zero of argumentation revealed that preservice teachers often had difficulty in providing adequate scientific evidence to support their claims; rather, they relied on personal experiences in their explanations. Preservice teachers' use of their personal opinions to address socioscientific issues rather than scientific data is also reported in past research (Albe, 2008; Hogan and Maglienti, 2001; Yang, 2005). For instance, Yang (2005) reported that students' reasoning modes are more driven by their personal epistemological perspective in environmental decision-making. While relying on personal opinions may be desirable to initially reveal how students conceptual a given issue, the integration of appropriate content and disciplined arguments is the aim of the pedagogical end game.

Naturally, one possible reason for preservice teachers' reliance on personal statements instead of scientific evidence may simply be their lack of experience in argumentation. Sampson and Blanchard (2012) stressed the importance of active participation in argumentation and highlighted that inexperienced people rely on their personal understanding about a phenomenon rather than seeking alternative sources to support their claims. However, a second and potentially more nuanced reason might be how media plays a significant role in how students come to frame and conceptualize features of socioscientific issues (Schreiner, Henriksen, and Hansen, 2005). In a study investigating science teachers' use of mass media to address SSI and sustainability issues (Klosterman, Sadler, and Brown (2012), researchers highlighted the possible risks of use of mass media without a critical lens on how those media are created. For preservice teachers in the present study, we suggest that not having more highly developed argumentation skills might lead them to passively accept ideas given through mass media sans critical evaluation. In our study, we also observed that the percentage of Level 0 argumentation was two times higher in alternative energy issue than the rest of the other issues. For this SSI, preservice teachers often had difficulty in providing adequate scientific evidence to support their claims and defaulted to their own personal experiences in their explanations. Presently, Turkey's most important infrastructure priority is energy (Demirbaş, 2003) and the country's demand for energy and electricity is increasing rapidly (Kaygusuz, 2009). Because of these reasons, Turkey's public has had constant exposure to news about energy issues, but may not have developed the critical lens to assess the efficacy of that information.

Regarding Level 1, Level 2, and Level 3 of argumentation, L3 argumentation was observed with highest frequency across all issues and similarly L2 and L1 were observed as the second and third highest level respectively. There might be several plausible reasons for observing changing frequencies of argumentation levels across issues. For example, context-specific knowledge influences students' explanations, evaluations, and use of evidence (Zhou et al., 2016) and also affects the students' willingness to invest a given issue. In the current study, the highest frequency of Level 2 argumentation scores was observed in the climate change issue. A plausible reason for this observation might be due to the complex nature of understanding the interrelated factors that contribute to climate change. Eggert, Nitsch, Boone, Nückles, and Bögeholz (2016) claimed that students might be lost in the complexity of the context. Climate change is a global environmental issue, driven by ideologies as much as it is rooted in science, and people have an array of views on this issue (Hulme, 2009). Ideologies, of course, in the contemporary use of the term, are impacted by a system of interconnected beliefs about particular means in order to achieve desired ends, usually involving political, economic and even moral systems of behavior (Zeidler and Newton, 2017). Hence, climate change is neither a simple "fact" waiting to be discovered nor a single 
Karıșan, D., Yılmaz Tüzün, Ö., \& Zeidler, D. L. (2017). Quality of preservice teachers argumentation in socioscientific issues context. Journal of Human Sciences, 14(4), 3504-3520. doi:10.14687/jhs.v14i4.4949

"problem" to be solved. In our study, although the preservice teachers have concern over climate change and express the desire to take responsibility for how some of their actions impact this issue, they were lacking the ability to integrate specific scientific evidence into their stances. This is understandable because people often receive multiple and conflicting messages about climate change that they then interpret in different ways (Hulme, 2009). Schreiner et al. (2005) reported that diverse media coverage, differing levels of reporting errors and deep time issues are also barriers for preservice teachers' understanding of climate change issues.

Lastly, another explanation for preservice teachers' varied scores from one issue to another might be the intrinsic motivation and personal experiences connected to that issue. In the last few decades, there has been a consensus that personal and motivational variables have an impact on learning (Bandura, 1986; 2016). Motivation enhances students' participation to learning activities or classroom discussions (Wlodkowski, 2011). For example, in the present study, the highest frequency of (Level 3) argumentation was found in the food additive issue. Throughout classroom discussions, preservice teachers were responsive to the information that they discovered and shared with their classmates, and were motivated to learn which foods they should consume (or not) for a healthier life-style. Earlier studies also support the finding that students are often engaged and sensitive to food-related issues because there is a concrete and assessable link between food and human health issues that personally affect them (Nazare, Disse, Vidal, and Laville, 2009).

\section{Conclusions and recommendations}

To conclude, the most important output of the present study was the fruitfulness of socioscientific issues in classroom discussions those let the preservice teachers share ideas, to coordinate different viewpoints, to communicate ideas, focus on alternative ideas.

Discussing socioscientific issues in class, developing a position and defending it, weighing the pros and cons is more effective than listening them from a professor during a lecture. Still, discussions have some disadvantages. PTs can easily start talking about off topic issues, but the investigators should be careful while interrupting off topic conversations as it may discourage preservice teachers and they can avoid participation in future discussions. We suggest the practitioners to have an informal discussion plan such as explicitly inform the participants about the goals of the discussion, specifically emphasize the importance of the issue, have opening questions to capture participants' attention. These recommendations are thought to help researchers breaking the barriers and flowing the discussions easily. Subject matter knowledge was found as an important factor that effect classroom discussion; present study did not test PTs subject matter knowledge at the beginning of the investigation, so we recommend future researchers to test subject matter knowledge at the beginning.

We recommend future researchers to use controversial discussions as the discussion is a natural and effective approach to engage learners in problem solving of real life issues that is necessary to be a good citizen. However, the researchers must be careful during the classroom discussions. The facilitator role of the researcher should be clearly defined and the researcher should not be a dominant factor during the classroom discussions. Controlling the discussion is important, researcher's role has utmost importance during the investigation but their being dominant during the discussions may decrease the number of opposing responses. If the participants feel uncomfortable then they will avoid engaging discussions. Thus, the researcher's reactions to the off-task conversations are determinant factor in classroom discussions. 
Karışan, D., Yılmaz Tüzün, Ö., \& Zeidler, D. L. (2017). Quality of preservice teachers argumentation in socioscientific issues context. Journal of Human Sciences, 14(4), 3504-3520. doi:10.14687/jhs.v14i4.4949

\section{References}

Albe, V. (2008). When scientific knowledge, daily life experience, epistemological and social considerations intersect: Students' argumentation in group discussions on a socio-scientific issue. Research in Science Education, 38, 67-90.

Aufschnaiter, C. V., Euduran, S., Osborne, J., \& Simon, S. (2008). Arguing to learn and learning to Argue: case studies of how students' argumentation relates to their scientific knowledge. Journal of Research in Science Teaching, 45(1), 101-131.

Bandura, A. (1986). Social foundations of thought and action: A social cognitive theory. PrenticeHall, Inc.

Bandura, A. (2016). Moral Disengagement: How People Do Harm and Live with Themselves, New York: Macmillan, 544. ISBN: 978-1-4641-6005-9.

Bell, R.L. \& Lederman, N.G. (2003). Understandings of the nature of science and decision making on science and technology based issues. Science Education, 87, 352-377.

Bell, P., \& Linn, M. C. (2000). Scientific arguments as learning artifacts: Designing for learning from the web with KIE. International Journal of Science Education, 22 (8), 797-817.

Berg, B. L. (2001). Qualitative Research Methods for the Social Sciences ( $4^{\text {th }}$ edition). Needham Heights, MA: Allyn \& Bacon.

Berland, L. K., \& Hammer, D. (2012). Framing for scientific argumentation. Journal of Research in Science Teaching, 49(1), 68-94.

Berland, L. K., \& Reiser, B. J. (2009). Making sense of argumentation and explanation. Science Education, 93, 26-55.

Callahan, B.E., Zeidler, D.L., Cone, N. \& Burek, K. (2005, October). The effects of learning socioscientific issues on reflective judgment in high school science students. Paper presented at the Annual Meeting of the Southeastern Association for Science Teacher Education, Athens, GA.

Demirbaş, A. (2003). Energy and environmental issues relating to greenhouse gas emissions in Turkey. Energy Conversion and Management, 44(1), 203-213.

Driver, R., Newton, P., \& Osborne, J. (2000). Establishing the norms of scientific argumentation in classrooms. Science Education, 84, 287-312.

Duschl, R. (2007). Quality argumentation and epistemic criteria. In S. Erduran \& M. JimenezAleixandre, (Eds.), Argumentation in Science Education: Perspectives from classroom-based research. Dordecht Netherlands: Springer.

Duschl, R. A., \& Osborne, J. (2002). Supporting and promoting argumentation discourse in science education. Studies in Science Education, 38 (pp. 39-72).

Eggert, S., Nitsch, A., Boone, W. J., Nückles, M., \& Bögeholz, S. (2017). Supporting Students' Learning and Socioscientific Reasoning About Climate Change the Effect of ComputerBased Concept Mapping Scaffolds. Research in Science Education, 47 (1), 137-159.

Evagorou, M. \& Osborne, J. (2013). Exploring young students' collaborative argumentation within a socioscientific issue. Journal of Research in Science Teaching, 50, 209-237. doi: $10.1002 /$ tea.2107

Erduran, S., \& Jiménez-Aleixandre, M. P. (2007). Argumentation in Science Education: Perspectives from classroom based research. Dordrecht, London: Springer.

Gage, N. L., \& Berliner, D. C. (1998). Educational psychology (6th ed.). Boston, MA: Houghton Mifflin.

Hogan, K., \& Maglienti, M. (2001). Comparing the epistemological underpinnings of students' and scientists' reasoning about conclusions. Journal of Research in Science Teaching, 38(6), 663-687.

Hulme, M. (2009). Why we disagree about climate change: Understanding controversy, inaction and opportunity. Cambridge University Press.

Jimenez-Aleixandre, M., Rodriguez, M., \& Duschl, R. A. (2000). 'Doing the lesson' or 'doing science': Argument in high school genetics. Science Education, 84 (6), 757- 792. 
Karışan, D., Yılmaz Tüzün, Ö., \& Zeidler, D. L. (2017). Quality of preservice teachers argumentation in socioscientific issues context. Journal of Human Sciences, 14(4), 3504-3520. doi:10.14687/jhs.v14i4.4949

Jimenez-Aleixandre, M. P., \& Pereiro- Munoz, C. (2002). Knowledge producers or knowledge consumers? Argumentation and decision making about environmental management. International Journal of Science Education, 24 (11), 1171-1190.

Kaygusuz, K. (2009). Energy and environmental issues relating to greenhouse gas emissions for sustainable development in Turkey. Renewable and Sustainable Energy Reviews, 13(1), 253-270.

Kelly, G. J., Chen, C., \& Prothero, W. (2000). The epistemological framing of a discipline: writing science in university oceanography. Journal of Research in Science Teaching, 37, 691-718.

Khisfe, R. (2013). Explicit Nature of Science and Argumentation Instruction in the Context of Socioscientific Issues: An effect on student learning and transfer. International Journal of Science Education. DOI: 10.1080/09500693.2013.832004.

Klosterman, M. L., Sadler, T. D., \& Brown, J. (2012). Science teachers' use of mass media to address socio-scientific and sustainability issues. Research in Science Education, 42(1), 51-74.

Kolstø, S. D. (2001). Scientific literacy for citizenship: tools for dealing with controversial socioscientific issues. Science Education, 85 (3), 291-310.

Kortland, K. (1996). An STS case study about students' decision making on the waste issue. Science Education, 80, 673-689.

Kuhn, D., \& Udell, W. (2003). The development of argument skills. Child Development, 74 (5), 1245 1260.

Lincoln, Y. S., \& Guba, E. G. (1985). Naturalistic inquiry. Thousand Oaks, CA: Sage.

Liu, S. Y., Lin, C. S., \& Tsai, C. C. (2011). College students scientific epistemological views and thinking patterns in social scientific decision making. Science Education, 95, 497-517.

Merriam, S. B. (1998). Qualitative research and case study applications in education. San Francisco, CA: Jossey-Bass.

Nazare, J. A., Disse, E., Vidal, H., \& Laville, M. (2009). Link between food and health: From gene expression to nutritional recommendations. Food quality and preference, 20(8), 537-538.

Newton, P., Driver, R., \& Osborne, J. (1999). The place of argumentation in the pedagogy of school science. International Journal of Science Education, 21(5), 553-576.

Ozdem, Y., Ertepinar, H., Cakiroglu, J., \& Erduran, S. (2013). The nature of pre-service science teachers' argumentation in inquiry-oriented laboratory context. International Journal of Science Education, 35(15), 2559-2586.

Özdem Yilmaz, Y., Cakiroglu, J., Ertepinar, H., \& Erduran, S. (2017). The pedagogy of argumentation in science education: science teachers' instructional practices. International Journal of Science Education, 39(11), 1443-1464.

Patton, M. Q. (2002). Qualitative research and evaluation methods. Thousand Oaks, CA: Sage.

Pouliot, C. (2008). Students' inventory of social actors concerned by the controversy surrounding cellular telephones: A case study. Science Education, 92(3), 543-559.

Rescnik, L. B. (2010). Nested Learning Systems for the Thinking Curriculum. Educatıonal Researcher, 39 (3), 183-197.

Rivard, L. P., \& Straw, S. W. (2000). The effect of talk and writing on learning science: an exploratory study. Science Education, 84, 566-593.

Schreiner, C., Henriksen, E. K., \& Kirkeby Hansen, P. J. (2005). Climate education: Empowering today's youth to meet tomorrow's challenges. Studies in Science Education, 41(1), 3-49, DOI: $10.1080 / 03057260508560213$

Sadler, T. D. (2011). Socio-scientific Issues in the Classroom: Teaching, Learning and Research. Springer.375.

Sampson, V. \& Blanchard, M. R. (2012). Science teachers and scientific argumentation: Trends in views and practice. Journal of Research in Science Teaching, 49, 1122-1148. doi: $10.1002 /$ tea.21037.

Sampson, V. \& Clark, D. (2008). Assessment of the ways students generate arguments in science education: Current perspectives and recommendations for future directions. Science Education, 92(3), 447-472. 
Karışan, D., Yılmaz Tüzün, Ö., \& Zeidler, D. L. (2017). Quality of preservice teachers argumentation in socioscientific issues context. Journal of Human Sciences, 14(4), 3504-3520. doi:10.14687/jhs.v14i4.4949

Stein, N.L. and Miller, C. A. (1991) I win-You lose: The development of Argumentative Thinking. In J.F. Voss, D.N. Perkins, and J.W. Segal (eds) Informal Reasoning and Education. (Hillsdale, New Jersey, Lawrence Erlbaum Associates) pp. 265-290

Toulmin, S. (1958). The uses of argument. Cambridge: Cambridge University Press.

Topcu, M. S., Sadler, T. D., \& Yilmaz-Tuzun, O. (2010). Preservice Science Teachers' Informal Reasoning about Socioscientific Issues: The influence of issue context. International Journal of Science Education.1, 1-21.

Voss, J.F. \& Van Dyke, J.A. (2001). Argumentation in Psychology. Discourse Processes, 32(2\&3), 89111.

Walker, K.A. \& Zeidler, D.L. (2007). Promoting discourse about socioscientific issues through scaffolded inquiry. International Journal of Science Education, 29(11), 1387-1410.

Wlodkowski, R. J. (2011). Enhancing adult motivation to learn: A comprehensive guide for teaching all adults. John Wiley $\&$ Sons.

Yacoubian, H. A. \& BouJaoude, S. (2010). The effect of reflective discussions following inquirybased laboratory activities on students' views of nature of science. Journal of Research in Science Teaching, 47, 1229-1252. doi: 10.1002/tea.20380

Yang, F. Y. (2005). Student views concerning evidence and the expert in reasoning a socio-scientific issue and personal epistemology. Educational Studies, 31(1), 65-84.

Zeidler, D.L., Berkowitz, M. \& Bennett, K. (2014). Thinking (scientifically) responsibly: The cultivation of character in a global science education community. In M.P. Mueller,D.J. Tippins \& A.J. Steward (Eds.), Assessing schools for generation R (Responsibility): A guide to legislation and school policy in science education. (pp. 83-99). The Netherlands: Springer.

Zeidler, D.L., Applebaum, S.M. \& Sadler, T.D. (2011). Enacting a socioscientific issues classroom: Transformative transformations. In T. D. Sadler (Ed.), Socio-scientific issues in science classrooms: Teaching, learning and research (pp. 277-306). The Netherlands: Springer.

Zeidler, D.L., Berkowitz, M. \& Bennett, K. (2014). Thinking (scientifically) responsibly: The cultivation of character in a global science education community. In M.P. Mueller,D.J. Tippins \& A.J. Steward (Eds.), Assessing schools for generation R (Responsibility): A guide to legislation and school policy in science education. (pp. 83-99). The Netherlands: Springer.

Zeidler, D.L. \& Lewis, J. (2003). Unifying themes in moral reasoning on socioscientific issues and discourse. In D.L. Zeidler (Ed.), The role of moral reasoning on socioscientific issues and discourse in science education. The Netherlands: Kluwer Academic Press. (pp. 289-306).

Zeidler, D.L., Sadler, T.D., Applebaum, S. \& Callahan, B.E. (2009). Advancing

reflective Judgment through socioscientific issues. Journal of Research in Science Teaching, 46(1), 74-101.

Zhou, S., Han, J., Koenig, K., Raplinger, A., Pi, Y., Li, D., ... \& Bao, L. (2016). Assessment of scientific reasoning: The effects of task context, data, and design on student reasoning in control of variables. Thinking Skills and Creativity, 19, 175-187. 